\title{
Factors associated with health-related quality of life among Indian women in mining and agriculture
}

\author{
Melba Sheila D'Souza ${ }^{1 *}$, Subrahmanya Nairy Karkada ${ }^{2}$ and Ganesha Somayaji
}

\begin{abstract}
Background: Women facing social and economic disadvantage in stressed communities of developing countries are at greater risk due to health problems. This paper investigates the relationships between structural, health and psychosocial predictors among women in mining and agricultural communities. This paper is a report of a study of the predictors of the health-related quality of life among Indian women in mining and agricultural communities.

Methods: A descriptive cross-sectional research design was used. The instruments used are SF-36 Health Survey and Coping Strategy Checklist. ANOVA, MANOVA and GLM were used in the analysis. The study was conducted between January-September 2008 with randomly selected women in a mining (145) and an agricultural community (133) in India.

Results: Women in the agricultural community had significantly increased Physical Health, Mental Health and SF36 scores compared with those in the mining community. Years of stay, education and employment were significant predictors among women in the agricultural community. 39\% (33\%) and 40\% (26\%) of the variance in Physical and Mental health respectively among women in agricultural and mining communities are predicted by the structural, health and psychosocial variables.

Conclusion: Perceived health status should be recognised as an important assessment of Physical and Mental Health among women in rural stressed communities. Cognitive, emotional and behavioural coping strategies are significant predictors of health related quality of life. Implications. Nurses should use the SF-36 as a diagnostic tool for assessing health related quality of life among women and discuss coping strategies, so that these can target women's adaptive behaviour. This should be an essential part of the nursing process for facilitating adaptive process for improved health related quality of life.
\end{abstract}

Keywords: SF-36, Health-related quality of life, Well-being, Perceived health, Women's health, Coping, Nursing, Mining

\section{Background}

Mining in India is an important developmental activity and has a manifold impact on population dynamics, development and environment. Men and women are differentially exposed or vulnerable to determinants of health $[1,2]$. Vulnerable groups, especially women, the elderly and children, often live in poorer socio-economic conditions and have poorer literacy skills compared with their urban counterparts [3]. Rural health status in stressed communities (e.g. mining) is lower than for non-stressed

\footnotetext{
* Correspondence: melba123@rediffmail.com

'Department of Adult Health and Critical Care, College of Nursing, Sultan Qaboos University, GSM, PO 66Al-Khoud, Muscat 123, Sultanate of Oman
} Full list of author information is available at the end of the article communities (e.g. agricultural) and limited access to health and welfare support services can further jeopardise the health status of rural women in India [4]. Studies also show that women's interaction with the biophysical environment within their own 'life spaces' reveals that they are exposed to the hazards of environmental illness in a manner that is clearly environmentally-differentiated (socio-economic, cultural and biophysical) from less stressed communities [5-9].

Health-related quality of life (HRQOL) is a perception of the degree of contentment with and capability to perform and control different facets of one's life [10-12]. For the purpose of our study HRQOL is defined as the perceived health status and daily functioning including physical and mental health, role limitations, and social 
functioning. Coping with stimuli is an important indicator of positive health status and is linked to healthrelated quality of life [13]. Coping strategies refer to behaviours adopted by women during stressful situations $[14,15]$. Coping is conceptualized as being an important personality variable representing cognitive, behavioural and emotional coping strategies targeted at modifying the cause of a stressful problem. Women differentially select particular coping strategies across stressful events $[16,17]$. This empirical research is a study of women's perceived health that could possibly be exerted by the structural (demographic, socio-economic), health (cultural, illness) and psychosocial (support, coping) factors contingent in mining and agricultural communities.

Living in mining communities exposes disadvantaged groups to health problems related to contamination of air, water, food, soil and river beds with toxic chemical and metallic discharges [18]. Women employed in the mines or collieries are exposed to toxic and hazardous substances due to poor safety, lack of control and monitoring measures and, as a result, and are susceptible to risks from several occupational illnesses [19]. Women living near coal and uranium mining in Bihar have succumbed to illness like malaria, typhoid and hepatitis, which were not prevalent before the mining activities. High infant mortality and deteriorating health among women were also common [20]. Women living near the Kolar gold fields travel far for meager wages to support their families, while most of the men are sick, depressed and unemployed due to the closure of the mines or have died in occupational accidents [20,21]. Most of the rural/tribal women due to mining-induced exploitation suffer from the social and particularly ill effects of mining-related hazards, pollution, poor waste disposal, denial of access to natural resources (water, forest, agriculture, land), incomplete rehabilitation, poor housing facilities, mine disasters, lack of livelihood, accidents, chemical spillage and closure [22,23]. These effects culminate in poor health and well-being among women depending on the thresholds of exposure in the mining communities compared to the less stressed communities.

\section{Review of literature}

Women face torture from security guards as they collect mud from the tailings to retrieve minute specks of gold. Unemployment has also led to the growth of anti-social activities like theft, fights and murder causing insecurity to women $[20,21]$. Incidences of alcoholism, drug addiction, prostitution, gambling, incest, wife swapping, infidelity, and domestic violence against women, have resulted in an increased risk of AIDS and STD among women living in mining areas [18]. The problems of the adivasi (local tribe) women due to the mining induced exploitation are poor quality of drinking water, roads, housing, agriculture produce, wife-battering, alcoholism, desertion, unemployment, starvation, gambling, infidelity, and AIDS [22].

In the coal mines of Hazarbagh, women are often scared, harassed and assaulted by the "coal mafia" [24]. Mining activities tend to reduce opportunities for women in Orrisa, thus increasing their levels of dependency and vulnerability.

AIDS have a specific impact on women in the mining town of Timika (West Papua, Indonesia) due to increasingly high levels of alcohol-related violence, infidelity, rape and prostitution. Most of the women in the mining areas are malnourished, prone to AIDS/STD infections, family violence, rape and prostitution, fueled by alcohol abuse [25]. The local women in the Soroako gold mining areas (Sulawesi, Indonesia) received welfare benefits like food packages after delivery, literacy classes, and medical services. There were also growing incidence of teenage pregnancy, alcoholism, rape and other forms of violence against women [26].

Hence stress and stressful life events are related to a number of disorders, both psychological and physical, among women [27,28]. Effective coping strategies such as support from social networks, and spirituality, can reduce stress, promote physical and mental wellbeing, and improve health. There is no review of literature regarding domestic violence, cultural beliefs, physical or mental health status and coping among women in the local mining community. A few local studies record high air, water and noise pollution, dumps, silt and loss of agricultural fields and poor quality of life among communities living in the mining regions [29-31]. This paper focuses on perceived women's health, use of coping strategies and health related quality of life. This is the first paper highlighting perceived women's health, coping and predictors of health-related quality of life in the mining villages compared to a non-stressed economic community (i.e. agricultural village).

\section{Conceptual framework}

Roy's adaptation model views the biopsychosocial individual as an adaptive system that must adapt to environmental stimuli [32]. Adaptation is considered to take place in one biological and three psychosocial modes as responses to the environment and to a particular situation which entail a great deal of motivation from the one involved [33]. In our study, a women's adaptive system (structural, health and psychosocial) coupled with coping processes through cognator and regulator subsystems act to maintain adaptation in the four adaptive modes: physiologic-physical, self-concept-group identity, role function, and interdependence (Figure 1).

We assessed the women's self-perceived health (dimensions) in each of the adaptive modes and the relevant 


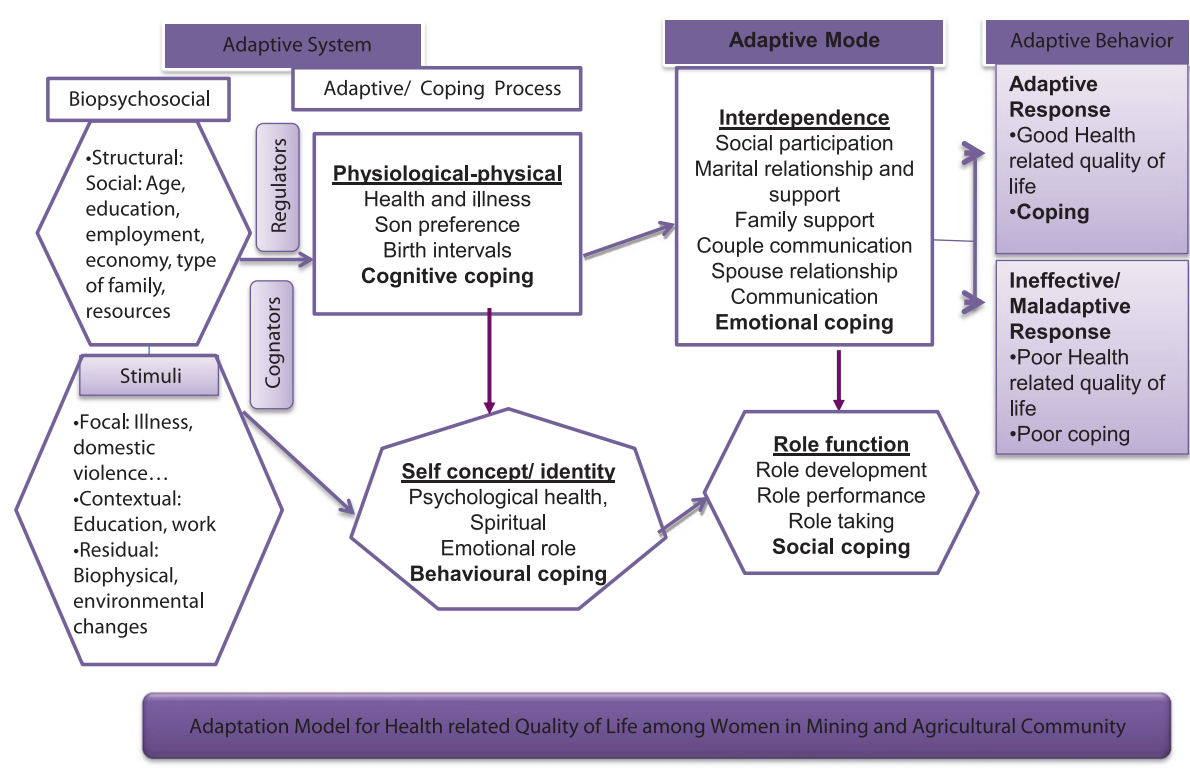

Figure 1 Adaptation model for health related quality of life among women in mining and agricultural community.

internal and external stimuli (focal, contextual, and residual) influencing those adaptive abilities in the mining and agricultural communities (Appendix A). Relationships between the adaptive modes occurs when stimuli affect more than one mode and coping processes are used to expand those abilities and to enhance environmental interactions to attain the goal, i.e., health status (adaptation). This identification leads to goal setting to promote adaptation in the four adaptive modes to enhance women's interaction with her immediate environment. Women's adaptive responses occur through use of adaptive process or coping strategies (cognitive, social, emotional, and behavioural) that help her integrate mutually with the environment resulting in adaptation. When all sub systems function well, adaptive behaviour (health related quality of life) occur, otherwise maladaptation (ineffective response) occurs. Nursing interventions should focus on altering these stimuli or strengthening adaptive processes to result in adaptive behaviours.

\section{Methods}

\section{Aim}

The aim of the study was to examine the relationship between health-related quality of life and possible predictors of HRQOL among Indian women in mining and agricultural communities.

\section{Design}

A descriptive cross-sectional research design was selected for the study.

\section{Settings and sampling}

This study has been conducted in the active iron ore mining villages in Goa which has a high air pollution index in 2008 [29,30]. A two-stage random sample was obtained from census tracts, electoral lists and family list from the Directorate of Health Services, local panchayats and the primary health centres respectively from the villages in the mining and agriculture communities (Figure 2).

The sample size was initially determined using G*Power software with the intention of using a linear multiple regression analysis [34,35] for the mining community. The sample size was calculated at a power of 0.9 with an effect size of 0.15 using 10 predictors (independent variables) with an alpha of 0.05 . The effect size was computed assuming a correlation coefficient of $0.3-0.4$ between the number of years living in a mining community (metric/variable) with Physical and Mental Health. It was found that a minimum sample size of 147 would be needed for these input parameters (rounded to 150). A matching sample size of 150 was decided for the agricultural community,

A multi-stage simple random sampling was used to select the women for the study (Figure 2). In the first stage in the North Goa district, Goa, five mining and five agricultural villages were selected randomly from the census tract from the Directorate of Health Services. In each selected village, 150 households were selected randomly from the electoral list from the local panchayats in both the communities. From the family registration list was obtained from the primary health centre, one woman was selected randomly from each household to make a total of 150 women in the mining and agricultural communities respectively. Women who met the eligibility 


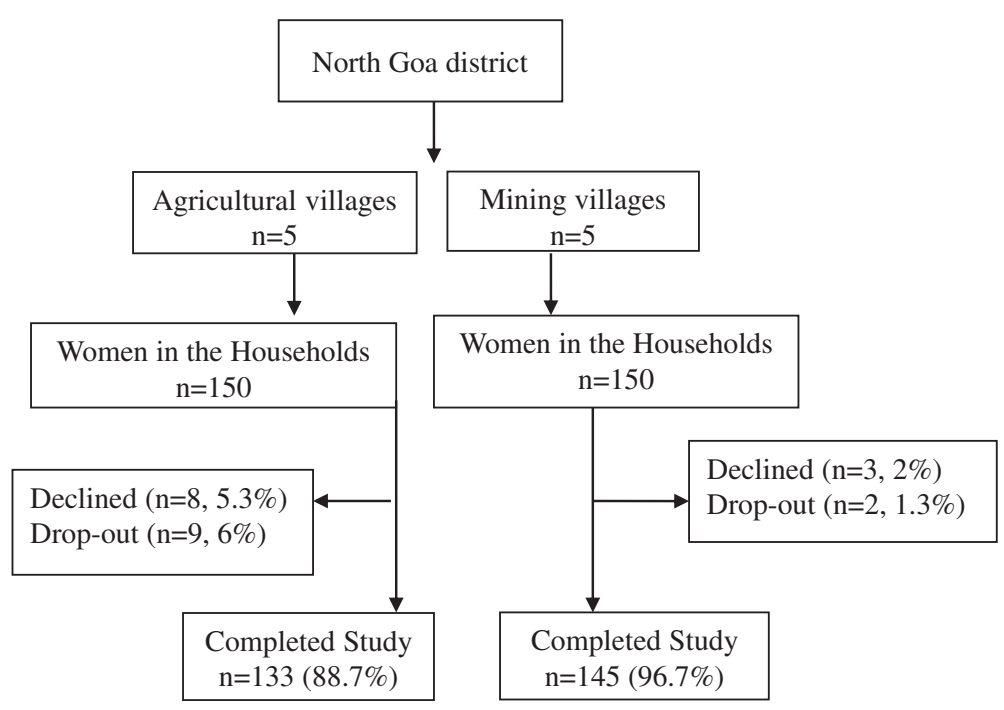

Figure 2 Multi-stage sampling strategy using simple random sampling.

criteria were included in the study. Five women dropped out of the study, so the actual sample size was reduced to 145 women in the mining community. Among the 150 randomly selected households in the agricultural community, 8 women declined to participate and 9 women dropped out due to time and personal constraints, making it 133 .

The inclusion criteria included local married women in the reproductive age group of 15-45 years who had borne at least one child, and women who are able to understand, converse, and communicate in Konkani and who would provide voluntary participation. We excluded women working in the mines.

\section{Data collection procedures}

The investigators reviewed validated and standardized tools on health status and coping. One standardized tool was selected to achieve the objectives of the study based on the background of the women.

\section{The SF-36 health survey (SF36)}

The SF-36 Health Survey (Version 1.0) also known as the Medical Outcomes Study, has been adapted for this study population after carefully considering the items and adaptation process [36-42]. It is a self-administered questionnaire of 36 items with closed-ended, structured questions and has 8 multi-item scales, which concentrate on the respondents' experiences, feelings, beliefs, perceptions and convictions concerning their healthrelated quality of life during the past four weeks [43-46]. The SF-36 Health Survey items and scales were constructed using the Likert scale method of summated ratings (Table 1). The first five scales make up the "Physical Health" or functional status dimension (subscale
1-5), and the last five form the "Mental Health" or well-being dimension (subscale 4-7). Hence, each dimension includes three specific and two overlapping (Vitality and General Health) scales. The SF-36 is divided into two aggregate summary measures, the Physical Component Summary or Physical Health (PCS or $\mathrm{PH}$ ) and the Mental Component Summary or Mental Health (MCS or PH).

The SF36 dimensions consist of: Physical functioning (PF, a pure physical health): 3-12 (10 items), Physical role limitations (RP): 13-16 (4 items), Bodily pain (BP): 21-22 (2 items), Vitality/energy/fatigue (VT): 23, 27, 29, 31 (4 items), General health (GH): 1, 33-36 (5 items), Mental health $(\mathrm{MH}$, a pure mental health): 24-26, 28, 30 (5 items), Social functioning (SF): 32, 20 (2 items) and Emotional role limitations (RE): 17-19 (3 items). The scores of the two dimensions and the total SF36 score are based on mathematical averaging of the scale components (summated ratings) which assume that items within a hypothesized scale can be summed up without score standardization or item weighting [47]. A higher score indicates better level of HRQOL.

The SF- $36{ }^{\circledR}$ Health Survey items and scales were constructed using the Likert method of summated ratings. Answers to each question are scored (some items need to be recoded). These scores are then coded and summed to produce raw scale scores for each health concept which are then reweighted/transformed to a 0 (worst health) -100 (best health) scale. Each scale score ranges from 0 to 100 , with a higher score indicating a better level of QOL. The SF-36 can also be divided into two aggregate summary measures the Physical Component Summary (PCS) and the Mental Component Summary (MCS). Scoring algorithms can then be applied to produce the PCS and MCS 
Table 1 SF-36 health survey consisting of eight health concept/scales/dimensions

\begin{tabular}{|c|c|c|}
\hline \multirow[t]{2}{*}{ Concepts } & SF 36 Health Dimensions & \multirow{2}{*}{$\begin{array}{l}\text { Total } \\
\text { items }\end{array}$} \\
\hline & Functional status subscales: $1,2,6,7$ & \\
\hline $\begin{array}{l}\text { 1. Physical functioning } \\
\text { (PF) }\end{array}$ & $\begin{array}{l}\text { Perceptions of quality of life that are influenced by their physical condition. Performing vigorous activities, moderate } \\
\text { activities or all types of physical activities including the most vigorous without limitation as a result of health. }\end{array}$ & 10 \\
\hline \multirow[t]{2}{*}{$\begin{array}{l}\text { 2. Physical role limitations } \\
\text { (RP) }\end{array}$} & $\begin{array}{l}\text { Performance of the roles in daily activities is impeded by their physical state of health, e.g. ability to perform } \\
\text { vigorous activities or moderate activities. }\end{array}$ & \multirow[t]{2}{*}{4} \\
\hline & $\begin{array}{l}\text { Physical limitations in performance of daily living. Problems encountered with daily activities or work as a result } \\
\text { of physical health or No problems with work or other daily activities as a result of physical health. }\end{array}$ & \\
\hline 6. Social functioning (SF) & $\begin{array}{l}\text { Social activities and interaction with significant others such as family members, friends, neighbours and other } \\
\text { social relations. Performance of social activities in lieu of health problem (eg, osteoarthritis) or normal social } \\
\text { activities without interference. }\end{array}$ & 2 \\
\hline \multirow[t]{2}{*}{$\begin{array}{l}\text { 7. Emotional - Role } \\
\text { limitations (RE) }\end{array}$} & $\begin{array}{l}\text { Emotional condition, e.g. feeling depressed or anxious, limits the daily functioning and ability to perform roles, } \\
\text { such as in cutting down on the amount of time spent on work or other activities and accomplishing less than } \\
\text { he/she would like to. Problems encountered with daily activities or work as a result of emotional health or No } \\
\text { problems with work or other daily activities as a result of emotional problems. }\end{array}$ & 3 \\
\hline & Wellbeing subscales: $3-5,8$ & \\
\hline 3. Bodily pain (BP) & $\begin{array}{l}\text { The scores on this dimension indicate to what extent the respondents' experience of bodily pain hinders their } \\
\text { performance of daily activities, including work-related duties in the public domain and tasks within the home } \\
\text { environment. Overall pain severity. No pain or limitations resulting from pain. }\end{array}$ & 2 \\
\hline \multirow{2}{*}{$\begin{array}{l}\text { 5. Vitality/energy/fatigue } \\
\text { (VT) }\end{array}$} & Feeling energetic and full of pep, or worn out and tired. & \multirow[t]{2}{*}{4} \\
\hline & Frequency of feeling full of energy vs tired. Feels full of pep and energy all of the time. & \\
\hline \multirow[t]{2}{*}{$\begin{array}{l}\text { 8. General Mental health } \\
\text { (MH) }\end{array}$} & $\begin{array}{l}\text { Psychological distress and psychological wellbeing dimension of the respondent is measured in terms of the } \\
\text { extent to which he/she is inter alia feeling full of pep, is happy, is feeling calm and peaceful, is very nervous, or is } \\
\text { feeling worn out and tired. Degree of nervousness or depression. Feels peaceful, happy }\end{array}$ & 5 \\
\hline & Overall evaluation of health subscale: 4 & \\
\hline \multirow[t]{2}{*}{$\begin{array}{l}\text { 4. General health } \\
\text { perceptions }(\mathrm{GH})\end{array}$} & $\begin{array}{l}\text { Concepts such as excellent, very good, good, fair or poor, getting ill easier than other people, and just as healthy } \\
\text { as anyone he/she knows. Overall general health. Evaluates personal health as excellent. }\end{array}$ & 5 \\
\hline & Total SF36 Health Survey scale & \multirow[t]{2}{*}{35} \\
\hline 36th question & "Compare health now with that one year ago?", is not included within these eight scales & \\
\hline
\end{tabular}

Note. Physical health: subscales 1-5, Mental health: subscales 4-8.

scores. (These two summary scores have the major advantage of being norm based. They also have reduced floor and ceiling effects.)

\section{Coping strategy checklist}

The investigators reviewed the Coping Orientation for Problem Experiences (COPE) Inventory [16], Ways of Coping Questionnaire [48,49] and the Revised Ways of Coping Checklist [50] and Reproductive health semistructured interview [51]. Based on these tools the investigators developed the Coping Strategy Checklist consisting of 25 items across four dimensions: Cognitive coping ([10] items): focused thinking, problem solving, reflection, belief/faith, identifying cause and consequences, anticipate, planning and prepare, systematic thinking, take precautions and relax. Behavioural coping ([5] items): use of health seeking behaviours, seeking medical treatment, spiritual help, assistance during illness and seeking help. Social coping ([4]) items: social participation, self-support groups, husband's support, family support. Emotional coping ([6] items): communication, wishful thinking, selfblame, avoidance and suppression. Example 'I talk to my husband to find out more about the situation,' 'I talk to my mother who could do something concrete about the problem'.

\section{Social and health status}

This demographic or socio-economic status tool (15 items) include age, years of stay, family type, socio-economic status, education, employment status, family economic status, house ownership and health problems of women.

\section{Ethical considerations}

Institutional Ethics Committee formed by Goa University approved the study and provided human and ethical clearance [52]. During the household visits the researchers interacted with the household members, built rapport with the family members, and sought participation among women and their spouses. This helped to gain co-operation with the women and their spouses during the data collection period in the area. In the mining and agricultural villages, 150 women selected randomly in each waddo (unit in each of the randomly selected village) were informed of the study by the research assistants through the primary 
health centres (Figure 2). They visited each woman participant in their houses to ascertain their participation, to develop a rapport and trusting relationship.

The purpose, procedures and ethical concerns of the study were informed to the local women. An introductory letter explaining the kind of research and the questionnaires was given to each woman randomly selected with the inclusion criteria from mining and agricultural villages. A verbal and a written informed consent document were obtained from the women indicating their voluntary participation and prerogative to withdrawal at any time. All women were assured that participation was voluntary, their anonymity, confidentiality of their responses, a blind analysis and a genuine use of the data would be adhered to. All the respondents were interviewed by the trained research assistants using the Konkani version of the tools. The women were interviewed in the privacy of their homes for 2 hours during convenient times from March-July 2008. Women were informed that the results would be reported accurately and that all shortcomings in the research, such as errors and limitations, would be disclosed [53-55]. Data were collected by trained interviewers directly from the selected women using pre-coded questionnaires. After the data collection the women were appreciated for their time and participation. All the tools were stored in locked cabinets with access to the researcher only.

\section{Data analysis}

Data quality was satisfactory, with a high response rate and use of all response categories, suggesting that there were no problems related to the translation of items and categories in the Surveys. Using Microsoft Excel 97, Version 9.0 (Microsoft, Redmond, WA), we used a method for the SF36 scoring of the subscales/dimensions and the total SF36 [56], multivariate analysis of variance and General Linear Model [57-59]. For trustworthiness and validation of the appropriateness of the survey tools, some women were interviewed after the data analysis to discuss the results and findings of the study. The data interpretation was according to the women's perception and experiences.

\section{Validity and reliability}

The SF36 Health Survey, Coping Strategy Checklist and the Social Health Status (English and Konkani versions) were validated with the content blueprint and threepoint evaluation criteria. These tools were adapted by forward and backward translation, iterative revision, and consensus by experts. Each translation was reviewed by three independent health-care providers, psychologists and sociologists who were proficient in both English and Konkani. The accuracy of the translations was certified. There was $100 \%$ strong agreement about the items in each domain among these subject experts.
The SF-36 was administered to 20 randomly selected women in both the mining and the agricultural communities in early January 2008 for pre-testing and a try-out. All participating women were able to answer the questionnaires independently within 90 minutes. The tools were found to be culturally sensitive, clear, relevant, and did not have any problems with its format or any aspects of the SF36 Health, Coping Strategy Scale and Social and Health Surveys.

The internal consistency of items was evaluated by analysis of correlations between the items and their respective scales. The internal consistency of the scales was calculated using Cronbach's alpha $\alpha$ coefficient. It is a measure of the extent to which items within the same scale correlate with each other. The $\alpha$ coefficient ranges from 0 to 1 : values greater than 0.70 are considered acceptable for group comparisons, and 0.90 for person-level comparisons [40]. The response rate for the scales was $100 \%$, i.e., all questions were answered by all women. Internal consistency reliability was high across most of the SF-36 subscales (>0.70) indicating a high level of correlation amongst items within the same subscale. The overall Cronbach's $\alpha$ coefficient of the SF-36 questionnaire was 0.76. Results showed that the SF-36 questionnaire demonstrated good reliability.

A pilot study was conducted in the February 2008 to assess the feasibility of the study, plan for the analyses and to determine the flaws in the design, using a random sampling technique with ten selected married women in the mining and agricultural communities. The pilot study did not show any problems or flaws in the design of the study.

\section{Results}

\section{Social health status}

A half-percentage of the women had a secondary education $(53.4 \%$ and $40 \%)$, while a quarter percentage of the women were illiterate $(23.3 \%$ and $24.8 \%)$ in the agricultural and mining communities respectively (Table 2 ). Only a few women were working after marriage (13.8\% and $46.6 \%$ ) compared with those before marriage (35.2\% and $44.3 \%$ ) in the mining community compared with the agricultural community. A substantial portion of the women had good $(62.1 \%$ and $36.1 \%)$ economic status in the mining community compared with the agricultural community respectively.

More women in the mining community reported domestic violence (19.3\% and 16.5\%) compared to the mining community. A greater percentage of women in the agricultural community used social (80.5\% and 69.7\%), cognitive (60.2\% and 20\%), emotional (53.4\% and 29\%) and behavioral (31.1\% and $26.2 \%$ ) coping strategies compared with to the women in the mining community respectively. 
Table 2 Socio-economic status among women in mining and agricultural communities

\begin{tabular}{|c|c|c|c|c|c|}
\hline \multirow[t]{2}{*}{ Socio-Economic Status } & \multirow[b]{3}{*}{ Category } & \multirow{2}{*}{\multicolumn{2}{|c|}{$\begin{array}{l}\text { Mining community } \\
\mathrm{N}=145\end{array}$}} & \multirow{2}{*}{\multicolumn{2}{|c|}{$\begin{array}{l}\text { Agricultural community } \\
\mathrm{N}=133\end{array}$}} \\
\hline & & & & & \\
\hline Variable & & $\mathrm{F}$ & $\%$ & $\mathrm{~F}$ & $\%$ \\
\hline \multirow[t]{3}{*}{ Age } & Less than 30 years & 36 & 24.8 & 37 & 27.8 \\
\hline & 30-39 years & 64 & 44.1 & 60 & 45.1 \\
\hline & More than 40 years & 45 & 31.0 & 36 & 27.1 \\
\hline \multirow[t]{2}{*}{ Marital status } & Living with husband & 139 & 95.9 & 127 & 95.5 \\
\hline & Separated/divorced & 6 & 4.1 & 6 & 4.5 \\
\hline \multirow[t]{3}{*}{ Years of stay } & Less than 10 years & 53 & 36.6 & 45 & 33.8 \\
\hline & $10-20$ years & 33 & 22.8 & 48 & 36.1 \\
\hline & More than 20 years & 59 & 40.7 & 40 & 30.1 \\
\hline \multirow[t]{2}{*}{ Family type } & Joint & 24 & 16.6 & 20 & 15.0 \\
\hline & Nuclear & 121 & 83.5 & 115 & 85.0 \\
\hline \multirow[t]{4}{*}{ Educational status } & No schooling & 36 & 24.8 & 31 & 23.3 \\
\hline & Elementary (till 4th) & 33 & 22.8 & 22 & 16.5 \\
\hline & Secondary (till 10th) & 58 & 40.0 & 71 & 53.4 \\
\hline & Vocational courses & 18 & 12.4 & 9 & 6.8 \\
\hline \multirow[t]{2}{*}{ Employment before marriage } & Farming & 9 & 6.2 & 51 & 38.3 \\
\hline & Unskilled & 42 & 29.0 & 8 & 6.0 \\
\hline \multirow[t]{3}{*}{ Employment after marriage } & Farming & 5 & 3.4 & 48 & 36.1 \\
\hline & Unskilled & 15 & 10.4 & 14 & 10.5 \\
\hline & Housewife & 125 & 86.2 & 71 & 58.4 \\
\hline \multirow[t]{3}{*}{ Economic status } & Good & 90 & 62.1 & 48 & 36.1 \\
\hline & Moderate & 37 & 25.5 & 51 & 38.3 \\
\hline & Poor & 18 & 12.4 & 34 & 25.6 \\
\hline \multirow[t]{2}{*}{ Domestic violence } & Wife beating & 28 & 19.3 & 22 & 16.5 \\
\hline & No assault & 117 & 80.7 & 98 & 73.7 \\
\hline \multirow[t]{2}{*}{ Emotional coping } & Present & 42 & 29.0 & 71 & 53.4 \\
\hline & Absent & 103 & 71.0 & 62 & 46.6 \\
\hline \multirow[t]{2}{*}{ Cognitive coping } & Present & 29 & 20.0 & 80 & 60.2 \\
\hline & Absent & 116 & 80.0 & 53 & 39.8 \\
\hline \multirow[t]{2}{*}{ Behavioural coping } & Present & 38 & 26.2 & 41 & 31.1 \\
\hline & Absent & 107 & 73.8 & 91 & 68.9 \\
\hline \multirow[t]{2}{*}{ Social coping } & Present & 101 & 69.7 & 107 & 80.5 \\
\hline & Absent & 44 & 30.3 & 26 & 19.5 \\
\hline \multirow[t]{3}{*}{ Ownership } & Own house & 103 & 71.0 & 119 & 89.5 \\
\hline & Rental house & 42 & 29.0 & 14 & 10.5 \\
\hline & Agricultural land & 29 & 20.0 & 59 & 44.0 \\
\hline
\end{tabular}

The women in the mining community reported more eye $(54.48 \%$ and $42.86 \%)$, upper respiratory $(30.34 \%$ and $24.06 \%$ ), lower respiratory (49\% and $19.55 \%$ ) and psychosomatic (52.41\% and 35.34\%) illnesses compared to those in the agricultural community (Table 3 ). Women in the agricultural community $(58.65 \%)$ reported more musculoskeletal illness than those in the mining community (48.28\%).

\section{Dimensions of the SF36}

To examine the mean values of the 8 dimensions of selfperceived health (HRQOL) among women in the mining 
Table 3 Enduring illness among women in the mining and agricultural communities

\begin{tabular}{|c|c|c|c|c|}
\hline \multirow[t]{2}{*}{ Physical and Mental Health } & \multicolumn{2}{|c|}{$\begin{array}{l}\text { Mining community } \\
\qquad \mathrm{N}=145\end{array}$} & \multicolumn{2}{|c|}{$\begin{array}{l}\text { Agricultural community } \\
\qquad N=133\end{array}$} \\
\hline & Freq & $\%$ & Freq & $\%$ \\
\hline Eye (inflammation, allergy, cataract) & 79 & 54.48 & 57 & 42.86 \\
\hline Ear (infection, hearing deficit, inflammation) & 16 & 11.03 & 18 & 13.53 \\
\hline Throat (inflammation, allergy, sore throat) & 11 & 7.59 & 16 & 12.03 \\
\hline Skin (infection, boils, allergy) & 14 & 9.66 & 11 & 8.27 \\
\hline Upper respiratory (common cold, sinus, dust allergy, dry cough) & 44 & 30.34 & 32 & 24.06 \\
\hline Lower respiratory (cough with phlegm, congestion, infection) & 49 & 33.79 & 26 & 19.55 \\
\hline Heart (chest pain, high BP, heart diseases) & 15 & 10.34 & 17 & 12.78 \\
\hline Musculoskeletal (severe backache, joint pain, neck pain, injury, foot problems) & 70 & 48.28 & 78 & 58.65 \\
\hline Digestive (severe backache, joint pain, neck pain, injury, foot problems) & 15 & 10.34 & 19 & 14.29 \\
\hline Endocrine (diabetes, thyroid) & 4 & 2.76 & 1 & 0.75 \\
\hline $\begin{array}{l}\text { Psychological (body ache, headache, fatigue, lethargy, reduced sleep, } \\
\text { insomnia, loss of sensation, dizziness, fainting, anxiety, worry) }\end{array}$ & 76 & 52.41 & 47 & 35.34 \\
\hline
\end{tabular}

and agricultural communities, ANOVA were used (Table 3).

H01 There is no significant difference between the SF36 mean scores among women in the mining and agricultural communities.

Among the 8 scales, women reported significantly higher scores on Physical Role Limitations (mean $=79.9$ and 57.8, p < 0.05) and Emotional Role Limitations (mean $=78.7$ and 73.1) in agricultural and mining communities (Table 4). Significantly higher differences were found in General Mental Health (mean = 69.8 and 63.6, $\mathrm{p}<0.05$ ) and Social Functioning (mean $=72.7$ and 65.9, $\mathrm{p}<0.01$ ) among women in the agricultural and mining communities. Higher mean scores were observed for Physical Role Limitations (mean =79.9), Emotional-Role Limitations (mean $=78.7)$, Bodily Pain $($ mean $=73.2)$, Social Functioning (mean $=72.7)$, General Mental Health $($ mean $=69.8)$, Vitality $($ mean $=61.8)$, General Health Perceptions (mean $=59.6)$, and Physical Functioning (mean $=53.7$ ) among women in agricultural compared with women in the mining community. Women in the agricultural community achieved a significantly higher SF36 (mean $=68.7$ and 62.7, $\mathrm{p}<0.05$ ), Physical health $(\mathrm{PH}) \quad($ mean $=65.6$ and 59.8, $\mathrm{p}<0.001)$ and Mental health $(\mathrm{MH})$ scores $($ mean $=68.5$ and 64.9, $\mathrm{p}<0.05)$ compared to women in mining community.

The Physical role limitations, Social functioning, Wellbeing/General Mental Health subscales, Physical Health, Mental Health and Total SF36 scales were the most valid measures of SF36 among women in the agricultural community. These items showed higher mean scores than Bodily pain, General health perceptions or Vitality and Emotional-role limitations, suggesting that these problems did not lead to significant impairment in the faily activities or under-reporting of sensitive issues related to impairment. The mean scores in all the scales were higher among women in the agricultural community than among women in the mining community.

\section{Predictors of HRQOL}

ANOVA was used to examine each of the predictors of Physical health, Mental health, and the total SF36 scores (Table 5). To reduce the number and size of the tables, all the categories of the predictors and the 8 sub-scales of the SF36 are not shown.

H01 There is no significant association between Physical and Mental Health means scores with Social Health Status and Coping Strategies among the women in mining as well as in the agricultural community.

There is a significant association between years of stay, education and employment status with the Physical Health, age, education, enduring illness, employment and behavioural coping with Mental Health and years of stay, education and employment with total health (SF36) and among women in the agricultural community (Table 5). A higher tendency to positive perception on HRQOL was observed with marital status, increased age, stay in the community, education, economic, employment status and ownership asset among women in the agricultural community. For SF36 a better perception of HRQOL is associated with absence of domestic violence and illness among these women. The existence of illness and domestic violence among women in the mining community promotes a less positive perception of HRQOL. The Physical Health component summary measure of the SF36 appeared to better explain differences in HRQOL among women in these communities.

A further General Linear Model (GLM) procedure was applied to investigate the relationship between $\mathrm{PH}$ and 
Table 4 SF36 among women in mining and agricultural communities using ANOVA

\begin{tabular}{|c|c|c|c|c|c|c|c|}
\hline \multirow[b]{2}{*}{ Scale } & \multirow{2}{*}{$\begin{array}{l}\text { Functional status and Well-being } \\
\text { SF36 Dimensions and items }\end{array}$} & \multicolumn{2}{|c|}{ Mining community $N=145$} & \multicolumn{2}{|c|}{ Agricultural community $\mathrm{N}=133$} & \multirow[b]{2}{*}{$\mathbf{F}$} & \multirow[b]{2}{*}{$\mathbf{P}$} \\
\hline & & Mean & SD & Mean & SD & & \\
\hline \multirow[t]{5}{*}{ Physical health } & 1.Physical Functioning (PF) & 50.1 & 26.1 & 53.7 & 21.1 & 1.5 & 0.22 \\
\hline & 2.Physical Role limitations (RP) & 57.8 & 44.6 & 79.9 & 35.3 & 20.8 & $0.00^{*}$ \\
\hline & 3.Bodily Pain (BP) & 69.3 & 25.1 & 73.2 & 19.9 & 2.0 & 0.15 \\
\hline & 4.General health perceptions $(\mathrm{GH})$ & 61.5 & 15.3 & 59.6 & 13.4 & 1.1 & 0.29 \\
\hline & 5.Vitality/energy/fatigue (VT) & 60.4 & 15.0 & 61.8 & 13.7 & 0.7 & 0.42 \\
\hline \multirow[t]{6}{*}{ Mental health } & 6.Social Functioning (SF) & 65.9 & 23.5 & 72.7 & 20.0 & 6.7 & $0.01^{*}$ \\
\hline & 7.Emotional-Role limitations (RE) & 73.1 & 43.2 & 78.7 & 37.9 & 1.3 & 0.25 \\
\hline & 8.Well-being or General Mental health (MH) & 63.6 & 16.0 & 69.8 & 15.2 & 10.9 & $0.00^{*}$ \\
\hline & Physical health & 59.8 & 15.8 & 65.6 & 13.7 & 10.7 & $0.00^{*}$ \\
\hline & Mental health & 64.9 & 15.5 & 68.5 & 13.1 & 4.4 & $0.04^{*}$ \\
\hline & Total SF36 & 62.7 & 15.9 & 68.7 & 13.6 & 11.1 & $0.00^{*}$ \\
\hline
\end{tabular}

* Significant at $\mathrm{p}<0.05$.

Physical health: subscales 1-5, Mental health: subscales 4-8.

$\mathrm{MH}$, interdependent variables with the predictors (independent variables) as seen in Tables 6 and 7 .

From the ANOVA tests (Table 5) factors such as younger age, marriage, shorter duration of stay in the community, employment, education, economic status, domestic violence, enduring illness, house ownership, social, cognitive, emotional and behavioral coping among women significantly predicted better Physical Health among women both in the agricultural and mining communities. Age, marriage, economic status, education, employment, ownership, domestic violence and illness significantly predicted better Mental health among women across both communities. Younger age, marital status, economic status, domestic violence, enduring illness, cognitive and behavioral coping among these women significantly predicted better SF36 scores. In addition, years of stay, education and work influenced Physical Health; age, education, enduring illness, work and behavioral coping led to better Mental Health and the SF36 scores was also influenced by years of stay, education and work among women in the agricultural community. Social coping improved Physical Health, cognitive coping affected Mental Health, and social and emotional coping predicted higher SF36 scores among women in the mining community.

The MANOVA models were used with all the variables in the ANOVA tests as predictors of $\mathrm{PH}$ and $\mathrm{MH}$ to test the combined effects of all independent variables together (Table 6). The MANOVA results are explained with the test of overall model significance and the test of overall individual effects of predictors. 39\% (33\%) and 40\% (26\%) of the variance in Physical and Mental Health among women was found in agricultural and mining communities respectively and was predicted by the structural, health and psychosocial coping variables. The Physical and Mental Health components were strongly correlated with the demographic (marital, employment status), cultural (domestic violence), health (enduring illness) and coping (social and cognitive) predictors. Though the $\mathrm{R}^{2}$ values were low, these results were used as indicative support of the relationship among the predictors. Physical and Mental Health have had a significant positive effect on HRQOL.

The test of overall model significance showed that the model is significant for each dependent variable ( $\mathrm{PH}$ and $\mathrm{MH}$ ) in the mining and the agricultural community. The "Tests of Between Subjects Effects" applies F test of significance to the relation of each covariate (age, illness, coping etc.) to each of the dependent variables ( $\mathrm{PH}$ and $\mathrm{MH}$ ). From the MANOVA test (Table 6) age, marriage, employment, economic status, domestic violence, social and cognitive coping significantly predicted Physical Health. Age, marital status, employment, economic status, social and cognitive coping predicted Mental Health among women across both the communities.

Women in the agricultural community had better Physical Health related to age, economic status, emotional and cognitive coping and better Mental Health related to age, ownership and economic status. Women in the mining community had better Physical Health predicted by marital status and social coping and Mental Health predicted by employment. The combined effect of predictors on $\mathrm{PH}$ and $\mathrm{MH}$ using Wilk's Lambda Multivariate Tests (Table 7) show illness, domestic violence, employment, social and cognitive coping among women in the mining and agricultural communities were significant predictors with this test (Table 7). Marriage and employment is the only other variable significant among women in the mining community whereas age, economic status and emotional coping emerged as other significant predictors among women in agricultural community. Marital status, domestic violence, social and cognitive coping were found 
Table 5 Structural, health and psychosocial predictors of HRQOL among women in mining and agricultural communities using ANOVA

\begin{tabular}{|c|c|c|c|}
\hline Predictors & SF36 & $\begin{array}{l}\text { Mining community } \\
\mathrm{N}=145, \mathrm{p}\end{array}$ & $\begin{array}{c}\text { Agricultural community } \\
\qquad N=133, p\end{array}$ \\
\hline \multirow[t]{3}{*}{ Age (years) } & $\begin{array}{l}\text { Physical } \\
\text { Health }\end{array}$ & $0.02^{*}$ & $0.00^{*}$ \\
\hline & $\begin{array}{l}\text { Mental } \\
\text { Health }\end{array}$ & 0.11 & $0.01^{*}$ \\
\hline & $\begin{array}{l}\text { Total } \\
\text { Health }\end{array}$ & $0.03^{*}$ & $0.00^{*}$ \\
\hline \multirow[t]{3}{*}{$\begin{array}{l}\text { Marital } \\
\text { status }\end{array}$} & $\begin{array}{c}\text { Physical } \\
\text { Health }\end{array}$ & $0.00^{*}$ & 0.09 \\
\hline & $\begin{array}{l}\text { Mental } \\
\text { Health }\end{array}$ & $0.00^{*}$ & $0.01^{*}$ \\
\hline & $\begin{array}{l}\text { Total } \\
\text { Health }\end{array}$ & $0.00^{*}$ & $0.03^{*}$ \\
\hline \multirow[t]{3}{*}{$\begin{array}{l}\text { Years of stay } \\
\text { in the area }\end{array}$} & $\begin{array}{c}\text { Physical } \\
\text { Health }\end{array}$ & 0.11 & $0.03^{*}$ \\
\hline & $\begin{array}{l}\text { Mental } \\
\text { Health }\end{array}$ & 0.37 & 0.12 \\
\hline & $\begin{array}{l}\text { Total } \\
\text { Health }\end{array}$ & 0.15 & $0.04^{*}$ \\
\hline \multirow[t]{3}{*}{$\begin{array}{l}\text { Educational } \\
\text { status }\end{array}$} & $\begin{array}{l}\text { Physical } \\
\text { Health }\end{array}$ & 0.34 & $0.00^{*}$ \\
\hline & $\begin{array}{l}\text { Mental } \\
\text { Health }\end{array}$ & 0.55 & $0.00^{*}$ \\
\hline & $\begin{array}{l}\text { Total } \\
\text { Health }\end{array}$ & 0.21 & $0.00^{*}$ \\
\hline \multirow[t]{3}{*}{ Family type } & $\begin{array}{l}\text { Physical } \\
\text { Health }\end{array}$ & 0.84 & 0.2 \\
\hline & $\begin{array}{l}\text { Mental } \\
\text { Health }\end{array}$ & 0.96 & 0.49 \\
\hline & $\begin{array}{l}\text { Total } \\
\text { Health }\end{array}$ & 0.99 & 0.26 \\
\hline \multirow[t]{3}{*}{$\begin{array}{l}\text { Economic } \\
\text { status }\end{array}$} & $\begin{array}{l}\text { Physical } \\
\text { Health }\end{array}$ & $0.00^{*}$ & $0.00^{*}$ \\
\hline & $\begin{array}{l}\text { Mental } \\
\text { Health }\end{array}$ & $0.02^{*}$ & $0.00^{*}$ \\
\hline & $\begin{array}{l}\text { Total } \\
\text { Health }\end{array}$ & $0.00^{*}$ & $0.00^{*}$ \\
\hline \multirow[t]{3}{*}{$\begin{array}{l}\text { Domestic } \\
\text { violence }\end{array}$} & $\begin{array}{l}\text { Physical } \\
\text { Health }\end{array}$ & $0.00^{*}$ & $0.00^{*}$ \\
\hline & $\begin{array}{l}\text { Mental } \\
\text { Health }\end{array}$ & $0.00^{*}$ & $0.00^{*}$ \\
\hline & $\begin{array}{l}\text { Total } \\
\text { Health }\end{array}$ & $0.00^{*}$ & $0.00^{*}$ \\
\hline \multirow[t]{3}{*}{$\begin{array}{l}\text { Enduring } \\
\text { illness }\end{array}$} & $\begin{array}{l}\text { Physical } \\
\text { Health }\end{array}$ & $0.00^{*}$ & $0.00^{*}$ \\
\hline & $\begin{array}{l}\text { Mental } \\
\text { Health }\end{array}$ & 0.24 & $0.01^{*}$ \\
\hline & $\begin{array}{l}\text { Total } \\
\text { Health }\end{array}$ & $0.03^{*}$ & $0.00^{*}$ \\
\hline
\end{tabular}

Table 5 Structural, health and psychosocial predictors of HRQOL among women in mining and agricultural communities using ANOVA (Continued)

\begin{tabular}{|c|c|c|c|}
\hline \multirow[t]{3}{*}{ Employment } & $\begin{array}{l}\text { Physical } \\
\text { Health }\end{array}$ & 0.13 & $0.01^{*}$ \\
\hline & $\begin{array}{l}\text { Mental } \\
\text { Health }\end{array}$ & 0.3 & $0.01^{*}$ \\
\hline & $\begin{array}{l}\text { Total } \\
\text { Health }\end{array}$ & 0.18 & $0.00^{*}$ \\
\hline \multirow[t]{3}{*}{$\begin{array}{l}\text { Ownership } \\
\text { asset }\end{array}$} & $\begin{array}{l}\text { Physical } \\
\text { Health }\end{array}$ & 0.65 & 0.76 \\
\hline & $\begin{array}{l}\text { Mental } \\
\text { Health }\end{array}$ & $0.04^{*}$ & $0.04^{*}$ \\
\hline & $\begin{array}{l}\text { Total } \\
\text { Health }\end{array}$ & 0.3 & 0.31 \\
\hline \multirow[t]{3}{*}{$\begin{array}{l}\text { Social } \\
\text { coping }\end{array}$} & $\begin{array}{l}\text { Physical } \\
\text { Health }\end{array}$ & $0.01^{*}$ & 0.43 \\
\hline & $\begin{array}{l}\text { Mental } \\
\text { Health }\end{array}$ & 0.24 & 0.44 \\
\hline & $\begin{array}{l}\text { Total } \\
\text { Health }\end{array}$ & $0.05^{*}$ & 0.89 \\
\hline \multirow[t]{3}{*}{$\begin{array}{l}\text { Cognitive } \\
\text { coping }\end{array}$} & $\begin{array}{l}\text { Physical } \\
\text { Health }\end{array}$ & 0.10 & $0.03^{*}$ \\
\hline & $\begin{array}{l}\text { Mental } \\
\text { Health }\end{array}$ & $0.01 *$ & 0.12 \\
\hline & $\begin{array}{l}\text { Total } \\
\text { Health }\end{array}$ & $0.02^{*}$ & $0.05^{*}$ \\
\hline \multirow[t]{3}{*}{$\begin{array}{l}\text { Emotional } \\
\text { coping }\end{array}$} & $\begin{array}{c}\text { Physical } \\
\text { Health }\end{array}$ & $0.01^{*}$ & $0.04^{*}$ \\
\hline & $\begin{array}{l}\text { Mental } \\
\text { Health }\end{array}$ & 0.07 & 0.66 \\
\hline & $\begin{array}{l}\text { Total } \\
\text { Health }\end{array}$ & $0.01^{*}$ & 0.22 \\
\hline \multirow[t]{3}{*}{$\begin{array}{l}\text { Behavioural } \\
\text { coping }\end{array}$} & $\begin{array}{l}\text { Physical } \\
\text { Health }\end{array}$ & $0.00^{*}$ & $0.00^{*}$ \\
\hline & $\begin{array}{l}\text { Mental } \\
\text { Health }\end{array}$ & 0.24 & $0.01^{*}$ \\
\hline & $\begin{array}{l}\text { Total } \\
\text { Health }\end{array}$ & $0.03^{*}$ & $0.00^{*}$ \\
\hline
\end{tabular}

to be significant predictors of the SF36 among women across both communities (Tables 6 and 7). In addition, age, economic status and emotional coping were significant predictors among women in the agricultural community.

\section{Discussion}

We could have employed an ethnographic qualitative research approach to assess the coping strategies used among women at different points in time to uncover explanations related to the why and how of the perceived health status. Future research should consider the use of a prospective longitudinal design to gather data for a better understanding of how women adapt over time with stress in economically stressed communities 
Table 6 Overall model significance and tests of between-subjects effects using GLM

\begin{tabular}{|c|c|c|c|c|c|c|c|c|}
\hline \multirow[t]{2}{*}{ Source } & \multirow[b]{2}{*}{ Health status } & \multirow[b]{2}{*}{ df } & \multicolumn{3}{|c|}{ Mining community $N=145$} & \multicolumn{3}{|c|}{ Agricultural community $N=133$} \\
\hline & & & Mean Square & $\mathbf{F}$ & $\overline{\mathrm{p}}$. & Mean Square & $\mathbf{F}$ & $\bar{p}$ \\
\hline \multirow[t]{2}{*}{ Corrected Model } & Physical health & 14 & 850.12 & 4.64 & $0^{*}$ & 697.58 & 5.49 & $0^{*}$ \\
\hline & Mental health & & 655.53 & 3.35 & 0 & 654.65 & 5.73 & $0^{*}$ \\
\hline \multirow[t]{2}{*}{ Intercept } & Physical health & 1 & 684.6 & 3.74 & 0.06 & 3476.2 & 27.37 & $0^{*}$ \\
\hline & Mental health & & 2073.6 & 10.59 & $0^{*}$ & 5733.86 & 50.22 & $0^{*}$ \\
\hline \multirow[t]{2}{*}{ Enduring illness } & Physical health & 1 & 1486.42 & 8.11 & $0.01^{*}$ & 564.12 & 4.44 & $0.04^{*}$ \\
\hline & Mental health & & 167.57 & 0.86 & 0.36 & 113.34 & 0.99 & 0.32 \\
\hline \multirow[t]{2}{*}{ Age } & Physical health & 1 & 427.57 & 2.33 & 0.13 & 1144.72 & 9.01 & $0^{*}$ \\
\hline & Mental health & & 274.35 & 1.4 & 0.24 & 1244.24 & 10.9 & $0^{*}$ \\
\hline \multirow[t]{2}{*}{ Marital status } & Physical health & 1 & 629.98 & 3.44 & 0.07 & 248.96 & 1.96 & 0.16 \\
\hline & Mental health & & 1523.03 & 7.78 & $0.01^{*}$ & 1035.69 & 9.07 & $0^{*}$ \\
\hline \multirow[t]{2}{*}{ Years of stay } & Physical health & 1 & 92.16 & 0.5 & 0.48 & 153.87 & 1.21 & 0.27 \\
\hline & Mental health & & 156.68 & 0.8 & 0.37 & 207.04 & 1.81 & 0.18 \\
\hline \multirow[t]{2}{*}{ Education } & Physical health & 1 & 204.76 & 1.12 & 0.29 & 182.34 & 1.44 & 0.23 \\
\hline & Mental health & & 80.75 & 0.41 & 0.52 & 60.52 & 0.53 & 0.47 \\
\hline \multirow[t]{2}{*}{ Family type } & Physical health & 1 & 157.01 & 0.86 & 0.36 & 0.29 & 0 & 0.96 \\
\hline & Mental health & & 24.47 & 0.12 & 0.72 & 172.06 & 1.51 & 0.22 \\
\hline \multirow[t]{2}{*}{ Employment } & Physical health & 1 & 853.15 & 4.66 & $0.03^{*}$ & 362.45 & 2.85 & 0.09 \\
\hline & Mental health & & 726.64 & 3.71 & 0.06 & 147.7 & 1.29 & 0.26 \\
\hline \multirow[t]{2}{*}{ Ownership } & Physical health & 1 & 0.77 & 0 & 0.95 & 0.05 & 0 & 0.98 \\
\hline & Mental health & & 504.24 & 2.58 & 0.11 & 571.89 & 5.01 & $0.03^{*}$ \\
\hline \multirow[t]{2}{*}{ Economic status } & Physical health & 1 & 326.1 & 1.78 & 0.18 & 797.2 & 6.28 & $0.01^{*}$ \\
\hline & Mental health & & 2.37 & 0.01 & 0.91 & 1171.78 & 10.26 & $0^{*}$ \\
\hline \multirow[t]{2}{*}{ Domestic violence } & Physical health & 1 & 3066.98 & 16.74 & $0^{*}$ & 1021.71 & 8.05 & $0.01^{*}$ \\
\hline & Mental health & & 1929.47 & 9.86 & $0^{*}$ & 1240.13 & 10.86 & $0^{*}$ \\
\hline \multirow[t]{2}{*}{ Emotional coping } & Physical health & 1 & 32.48 & 0.18 & 0.67 & 690.2 & 5.44 & $0.02^{*}$ \\
\hline & Mental health & & 26.65 & 0.14 & 0.71 & 70.7 & 0.62 & 0.43 \\
\hline \multirow[t]{2}{*}{ Behavioural coping } & Physical health & 1 & 54.86 & 0.3 & 0.59 & 117.13 & 0.92 & 0.34 \\
\hline & Mental health & & 338.15 & 1.73 & 0.19 & 229.14 & 2.01 & 0.16 \\
\hline \multirow[t]{2}{*}{ Social coping } & Physical health & 1 & 2650.92 & 14.47 & $0^{*}$ & 27 & 0.21 & 0.65 \\
\hline & Mental health & & 688.86 & 3.52 & 0.06 & 378.83 & 3.32 & 0.07 \\
\hline \multirow[t]{2}{*}{ Cognitive coping } & Physical health & 1 & 622.34 & 3.4 & 0.07 & 719.18 & 5.66 & $0.02^{*}$ \\
\hline & Mental health & & 1172.41 & 5.99 & $0.02^{*}$ & 577.85 & 5.06 & $0.03^{*}$ \\
\hline
\end{tabular}

$\# \mathrm{df}=1{ }^{*}$ Significant at $\mathrm{p}<0.05$. Computed using alpha $=0.05$.

Mining. Physical health: R2 $=0.333$ (Adjusted R squared $=0.261$ ), Mental health $R 2=0.265$ (Adjusted R squared $=0.186$ ). Agricultural. Physical health: R2 $=0.397$ (Adjusted R squared $=0.324$ ), Mental health: $R 2=0.407$ (Adjusted $R$ squared $=0.336$ ).

and how this affects various dimensions of their healthrelated quality of life.

Women in the agricultural community scored higher on all dimensions of Physical functioning (PF), Physical role limitations (RP), Bodily pain (BP), Vitality/energy/fatigue, General health (GH), Mental health $(\mathrm{MH})$, Social functioning (SF) and Emotional role limitations (ER) compared with women in mining. The perception of decreased illness and domestic violence is a significant predictor of health status among women in agriculture.
They had higher education, employment, ownership and more coping strategies which paralleled a marked increase in PH, MH and SF36 scores among these women. These women perceived more role functions, a better self-concept and interdependence and felt the need to return to gainful employment and family roles. This shows a reciprocal relationship between physical role limitations, social functioning and general mental health among women that supports the higher order components (Physical health, Mental health and Total health). 
Table 7 Combined effect of predictors on SF36 using Wilk's Lambda Multivariate analysis of variants Tests (MANOVA/ GLM)

\begin{tabular}{|c|c|c|c|c|c|c|}
\hline \multirow{2}{*}{$\begin{array}{l}\text { Wilks' Lambda } \\
\text { Effect }\end{array}$} & \multicolumn{3}{|c|}{ Mining community $\mathrm{N}=145$} & \multicolumn{3}{|c|}{ Agriculture $\mathrm{N}=133$} \\
\hline & Value & $F$ & $\bar{p}$ & Value & $F$ & $\mathrm{p}$ \\
\hline Intercept & 0.92 & 5.46 & $0.01^{*}$ & 0.70 & 24.95 & $0.00^{*}$ \\
\hline Enduring illness & 0.92 & 5.44 & $0.01^{*}$ & 0.96 & 2.44 & 0.09 \\
\hline Age & 0.98 & 1.16 & 0.32 & 0.91 & 5.85 & $0.00^{*}$ \\
\hline Marital status & 0.94 & 3.90 & $0.02^{*}$ & 0.92 & 5.01 & $0.01^{*}$ \\
\hline Years of stay & 0.99 & 0.40 & 0.67 & 0.98 & 0.92 & 0.40 \\
\hline Education & 0.99 & 0.57 & 0.57 & 0.99 & 0.73 & 0.49 \\
\hline Family type & 0.99 & 0.54 & 0.59 & 0.97 & 1.57 & 0.21 \\
\hline Employment & 0.96 & 2.44 & 0.09 & 0.98 & 1.42 & 0.25 \\
\hline Ownership & 0.96 & 2.58 & 0.08 & 0.92 & 4.88 & $0.01^{*}$ \\
\hline Family economic status & 0.97 & 1.68 & 0.19 & 0.92 & 5.15 & $0.01^{*}$ \\
\hline Domestic violence & 0.89 & 8.33 & $0.00^{*}$ & 0.91 & 5.64 & $0.00^{*}$ \\
\hline Emotional coping & 1.00 & 0.09 & 0.91 & 0.94 & 3.42 & $0.04^{*}$ \\
\hline Behavioural coping & 0.98 & 1.04 & 0.36 & 0.98 & 1.00 & 0.37 \\
\hline Social coping & 0.89 & 8.04 & $0.00^{*}$ & 0.93 & 4.65 & $0.01^{*}$ \\
\hline Coginitive coping & 0.96 & 2.97 & $0.05^{*}$ & 0.95 & 3.13 & $0.05^{*}$ \\
\hline
\end{tabular}

*Significant at $\mathrm{p}<0.05$. Design: Intercept + enduring illness (present**, absent) + age (less than 30, 30-39 and more than 40 years**) + marital status (living with husband, separated/divorced $\left.{ }^{* *}\right)+$ years of stay (less than 10,10-20, more than 20 years**) + education (no schooling, elementary, secondary, vocational**) + family type (joint ${ }^{* *}$, nuclear) + family economic status (good ${ }^{* *}$, moderate, poor) + domestic violence(wife beating ${ }^{* *}$, no assault) + emotional coping (present**, absent) + behavioural coping(present ${ }^{* *}$, absent) + social coping(present ${ }^{* *}$, absent) + coginitive coping(present ${ }^{* *}$, absent). ${ }^{* *}$ Reference groups used in regression.

This stipulates that their good physical health presupposes good mental health and vice versa among women in the agricultural community. Coping strategies were significantly higher and positively related to the HRQOL among women in the agricultural community. Higher capacity for coping are positively associated with HRQOL [60-63] which showed higher capacity for coping and positively associated with quality of life [64].

Women in the mining community reported higher levels of eye, upper and lower respiratory and psychological illness as well as higher percentage of domestic violence. This can be explained by less exposure to education, employment, experiencing stressful events (environmental stress like dust and air pollution) and lack of power, control and autonomy $[65,66]$. Stress and stressful life events are related to a number of disorders, both psychological and physical, among women $[27,28,67,68]$. Clinical variables (symptoms, demographic, biological, physiological factors) are linked to and are predictive of HRQOL $[69,70]$. The connection between domestic violence and illness is a significant predictor of poor Physical and Mental Health.

Age, economic status, years of stay, domestic violence and illness are significantly associated with quality of life and reproductive health index among women in the mining community [51]. Age, marital duration, poverty, gender inequities, husband's employment [17] and gender-based power dynamics [71,72] emerged as the risk factors of victimization and the perpetration of all types of domestic violence. Educated [73] and regularly employed women are typically more autonomous and possess the resources and skills necessary to better recognize and terminate a potentially abusive relationships and were less likely to report ever having experienced physical domestic violence than unemployed women [71].

The SF36 correlates were high with decreased illness, age, marital status, ownership asset, domestic violence, emotional, social and cognitive coping among women in the agricultural community. In our study, role functions, social valuing of role expectations and mental health has been identified as motivators in the development of good HRQOL among women in the agricultural community. Women's health differs in various communities because they also react in different ways to predictors that determine health. Health status in stressed communities (mining) is lower than for non-stressed communities (agricultural), and limited educational and employment can further jeopardise health status. The socio-cultural environment exerts a constraining impact on coping and the SF36 among women in mining communities, leading to a stressful life; while limited educational and employment opportunities may compound to aggravate Physical and Mental Health.

\section{Conclusion}

In our study Physical and Mental Health have significantly positive and direct influence on the HRQOL among 
women. HRQOL is determined by complex layers of intertwined forces, with structural (age, marital status, economic, family type, ownership), health (illness, domestic violence) and psychosocial (social, emotional, cognitive and behavioural coping strategies) predictors of Physical and Mental Health among women in the agricultural and mining communities. Psychosocial resources, health and stressful events are rooted in the social structural context of women's lives. In addition years of stay, education and employment are significant predictors among women in the agricultural community. Cognitive-perceptual factors and self-efficacy were significant predictors of health promoting lifestyle and HRQOL [74].

The differential pattern of responses related to cultural and health (domestic violence, illness), socio-economic factors (education, employment, economy) and coping strategies (social, emotional, behavioural and cognitive) signifies exposure to focal (unsupportive relationships, violence), contextual (job stress, financial instability) or residual (environmental stress) stimuli, are positively associated with the SF36 dimensions among women in the mining and agricultural communities. These stimuli have both direct and mediating responses on HRQOL which explain the differences in perceived health among women across both communities. This perspective helps to illuminate those aspects of the adaptive system that contribute to a differential exposure to stimuli and to the coping strategies (resources) that women mobilize against stimuli or problems $[2,5,75]$.

Coping strategies or resources (cognitive and emotional) vary in their benefits and are positively related to better HRQOL among women in various communities. Women's coping strategy (psychosocial predictors) is an important factor which affects health outcomes and influences HRQOL. The SF36 dimensions (HRQOL) were found to reflect the health status of women and were also significantly associated with coping with stress which plays a key role in women's physical and mental health. Coping style has a strong association with life satisfaction and well-being [76]. Coping strategies and resources play an important role in determining adaptation to health related quality of life, but their effects have been stronger for women in the agricultural compared with the mining community. Women apply specific coping strategies when encountering stimuli, for example cognitive coping attempts to alter and manage the stressor, whereas emotional/social coping attempts to regulate the emotional response to the stressor. Our results contribute to an increase in awareness of coping as important indicators of successful adaptation. Cognitive coping improves health status and was positively related to better quality of life among women in the agricultural community. Women who are not able to maintain physiologic-physical needs (polluted environmental, mental stress), poor self-concept, inadequate role function as a family member, spouse, interdependence (poor self-esteem, poor communication), find it difficult to maintain daily activities and interaction with significant others such as family members. Women in the agricultural communities are at a greater advantage with better biopsychosocial, coping processes and adaptive modes leading to effective responses and adaptive behaviours. This study shows that structural, health and psychosocial predictors determine HRQOL among women in both the communities.

\section{Implications for nursing}

SF-36 is a diagnostic tool for nurses to assess the functional health patterns and perceived health needs of high-risk women subgroups in vulnerable populations and settings. Self-assessment of health is important to facilitate more individualized nursing care to promote HRQOL among women. Identification of stimuli and coping strategies that are predictive of health status are critical to the development of coping strategies in these populations of women. Nurses can address the importance of valuing role functions among women and this information can be used for designing appropriate nursing interventions. Thereby women can be empowered to make informed decisions and to act on them. This ability to discriminate across vulnerable populations means that nurses can use SF36 health scores to better understand functional status and the health care needs of atrisk women sub-groups. This will enable health policy makers to evaluate the health status and outcomes among women for enhance policy making towards optimum resource management and provision of safe environment.

\section{Appendix A}

\section{Definition of terms}

Focal stimuli are those most immediately confronting the person.

Contextual-all other stimuli present that are affecting the situation and Residual- those stimuli whose effect on the situation are unclear.

Adaptation: the process and outcome whereby thinking and feeling persons, as individuals and in groups, use conscious awareness and choice to create human and environmental integration

Adaptive Responses: responses that promotes integrity in terms of the goals of the human system, that is, survival, growth, reproduction, mastery, and personal and environmental transformation

Ineffective Responses: responses that do not contribute to integrity in terms of the goals of the human system

An adaptive system with coping processes, cognator and regulator subsystems acting to maintain adaptation in the 
four adaptive modes: physiologic-physical, self-conceptgroup identity, role function, and interdependence.

Regulators regulate four adaptive modes through neuro chemical or endocrine activities. Cognator are the control subsystem. Roys view the regulators and cognator as method of coping. When all six sub systems function well adaptative behaviour will occur otherwise ineffective response or maladaptation will occurs.

\section{Adaptive modes}

Physiologic-physical. Physical and chemical processes involved in the function and activities of living organisms; the underlying need is physiologic integrity as seen in the degree of wholeness achieved through adaptation to change in needs. Five needs-oxygenation, nutrition, elimination, activity and rest, protection. For complex processes-senses; fluid, electrolyte, and acid-base balance; neurologic function; endocrine function

Self-concept-group identity. Focuses on psychological and spiritual integrity and sense of unity, meaning, and purposefulness in the universe. Need is psychic and spiritual integrity so that one can be or exist with a sense of unity, meaning, and purposefulness in the universe

Role function. Roles that individuals occupy in society, fulfilling the need for social integrity. It is knowing who one is in relation to others. Need is social integrity; knowing who one is in relation to others so one can acct; role set is the complex of positions individual holds; involves role development, instrumental and expressive behaviors, and role taking process

Interdependence: The close relationships of people and their purpose, structure and development individually and in groups and the adaptation potential of these groups. Need is to achieve relational integrity using process of affectional adequacy, i.e., the giving and receiving of love, respect, and value through effective relations and communication.

\section{Research highlights}

- Physical and Emotional Role Limitations are motivators to promote coping among women for health related quality of life.

- Age, marital status, economic status, family type, ownership, illness and domestic violence are predictors among women.

- Cognitive, emotional and behavioural coping strategies influence women's Physical and Mental health and health-related quality of life.

- SF-36 Health Survey should be used to assess and plan nursing interventions for improving health-related quality of life.

\section{Abbreviations}

BP: Bodily pain; GH: General health; HRQOL: Health-related quality of life; MCS: Mental health component summary; MH: Mental health; PCS: Physical component summary; PF: Physical functioning; RE: Role emotional; RP: Role physical; SF: Social functioning; SF-36: Short form 36-item health survey; VT: Vitality; PH: Physical health; QOL: Quality of life.

\section{Competing interests}

The authors declare that they have no potential competing interests.

\section{Authors' contributions}

All authors meet the criteria for authorship, have designed, provided analysis and interpreted the data, drafted, revised and approved the final article and those entitled to authorship are listed as authors. MSD conceived of the study conception and design, data collection/acquisition, and provided analysis and interpretation. KSN participated in the data collection/ acquisition and provided analysis and interpretation. GS carried out the study conception and design. All the authors drafted the manuscript, provided critical revision of manuscript for important intellectual content and final approval of version to be submitted. MSD-Melba Sheila D'Souza; KSN- Karkada Subrahmanya Nairy; GS-Ganesha Somayaji.

\section{Acknowledgements}

The investigators would like to thank the village local panchayats (authorities) for the permission, local women participants and research assistants for their support, voluntary participation and collecting data. We thank Dr William Reginald Schreck and Dr Derick Smith for their professional proof-reading and editing of the paper. We are indebted to the journal editors and the reviewers for their incisive comments which have greatly improved this paper.

\section{Funding}

This is a self funded empirical research carried out with the author's interest.

\section{Author details}

'Department of Adult Health and Critical Care, College of Nursing, Sultan Qaboos University, GSM, PO 66Al-Khoud, Muscat 123, Sultanate of Oman. ${ }^{2}$ Department of Business Studies, Higher College of Technology, Al Khuwair, Ministry of Manpower, Muscat, Sultanate of Oman. ${ }^{3}$ Department of

Sociology, Goa University, TaleigaoPlatuea, Goa, India.

Received: 30 May 2012 Accepted: 11 January 2013 Published: 22 January 2013

\section{References}

1. Walters V, Lenton R, McKeary M: Women's health in the context of women's lives. Ottawa: Minister of Supply and Services Canada; 1995.

2. Walters V, McDonough P, Strohschein L: The influence of work, household structure, social, personal and material resources on gender differences in health: an analysis of the 1994 Canadian national population health survey. Soc Sci Med 2002, 54(5):677-692.

3. Umberson D, Chen MD, House JS, Hopkins K, Slaten E: The effect of social relationships on psychological well-being: are men and women really so different? Am Sociol Rev 1996, 61:837-857.

4. Babu BV, Kar SK: Domestic violence in Eastern India: factors associated with victimization and perpetration. Public Health 2010, 124:136-148.

5. Denton $M$, Walters V: Gender differences in structural and behaviorual determinants of health: an analysis of the social production of health. Soc Sci Med 1999, 48:1220-1235.

6. Denton M, Prus S, Walters V: Gender differences in health: a Canadian study of the psychosocial, structural and behavioural determinants of health. Soc Sci Med 2004, 58:2585-2600.

7. Hunt $K$, Annadale E: Relocating gender and morbidity: examining men's and women's health in contemporary Western societies. Introduction to social issue on gender and health. Soc Sci Med 1999, 48:1-5.

8. Macintyre H, Sweeting $\mathrm{H}$ : Gender differences in health: are things really as simple as they seem? Soc Sci Med 1996, 42(4):617-624.

9. Smith KR, Waitzman N: Double jeopardy: interaction effects of martial and poverty status on the risk of mortality. Demography 2010, 31:487-507.

10. Ware JEJ, Sherbourne CD: The MOS 36 item short form health survey (SF 36): conceptual framework and item selection. Medical Care 1992, 30:473-483. 
11. Ware JE Jr, Kosinski M, Bayliss MS, McHorney CA, Rogers WH, Raczek A: Comparison of methods for the scoring and statistical analysis of SF 36 health profile and summary measures: summary of results from the medical outcomes study. Medical Care 1995, 33:AS264-AS279.

12. Wenger NK, Mattson ME, Forsberg CD, Elinson J: Assessment of quality of life in clinical trials of cardiovascular therapies. Am J Cardiol 1984, 54(7):908-913.

13. Chang Y: Psychometric validity of the problem focused style of coping scale in relation to self-efficacy and life satisfaction among nursing staff in Taiwan. J Adv Nurs 2011, 67(7):1625-1631.

14. Chen KH, Ku NP: Relationship among stressors, coping behaviours and life satisfaction of adults after heart transplantation. Nurs Res 1997, 5(1):41-51.

15. Hu HL: The relationship between social support and coping in critical care patients in Taiwan. Veterans Nurs J 1992, 9(2):194-200.

16. Carver CS, Scheier MF, Weintraub JK: Assessing coping strategies: a theoretically based approach. J Personal Soc Psychol 1989, 56(2):267-283.

17. Endler NS, Parker JDA: Multidimensional assessment of coping: a critical evaluation. J Personal Soc Psychol 1990, 58:844-854.

18. Tauli Corpuz V: The globalisation of mining and its impact and challenges for women. Baguio: International conference on women and mining; 1997.

19. WISE News Communique' report: Water resource Management's bulletin 71st edition: 2003:50-78. Retrieved May 28 2005. http://www.wrm.org.uy/ bulletin/71/women.html.

20. Defending Our Lives, Demanding Our Rights: International women \& mining conference. Mines minerals and people: 2004. http://www.mmpindia.org/ womenandminigreport.pdf.

21. India: Women's response to devastating mining: 2005. http://www.wrm.org. uy/bulletin/80/India.html.

22. Women in mining struggles in India: The invisibility of gender concerns in mining struggles: 2003. http://www.minesandcommunities.org.

23. Nair J: Representing labour in Old Mysore: kolar gold fields strike of 1930. Econ Political Weekly 1990, 25(30):73-86.

24. Bhanumathi K: The status of women affected by mining in India women: mining and communities. Tunne/ Vision 2002, 1:1. http://www.caa.org.au/ campaigns/mining/women/tunnelvisionpapers/kbhanumathi.html.

25. Silitonga NRA, Wignall FS: Mining and HIV in west Papua: mining, HIV/ AIDS and women in timika, Papua province, Indonesia. Down to Earth 2003, 57(2):76-89. http://www.caa.org.au/campaigns/mining.

26. Robinson K: The soroaka nickel project: a healthy development. Int Health Sci 2000, 15(2):67-89.

27. Hogue CJR: Gender, race and class: from epidemiologic association to etiologic hypotheses. In Women and Health. Edited by Goldman MB, Hatch MC. San Diego: Academic; 2000:15-23.

28. Williams K, Umberson D: Women stress, and health. In Women and health Edited by Goldman MB, Hatch MC. San Diego: Academic; 2000:553-562.

29. The Energy and Resources Institute: Areawide environmental quality management plan for the mining belt of Goa. Report 96/EE/63, Directorate of planning statistics and evaluation. Goa: Government of Goa; 1997.

30. The Energy and Resources Institute: Environmental social performance indicators and sustainability markers in minerals development: reporting progress towards improved health and human well being phase I, Report 97WR52. 1999. Goa: The Energy and Resources Institute; 1999.

31. The Energy and Resources Institute: Environmental social performance indicators and sustainability markers in minerals development: Reporting progress towards improved health and human well being Phase II, Report 2000WR41. Goa: The Energy and Resources Institute; 2002

32. Roy C: The Roy adaptation model. In Conceptual models for nursing practice. Edited by Riehl JP, Roy C. Norwalk: Appleton: Century Crofts; 1980

33. Alligood MR, Tomey AM: Nursing theorists and their work. 7th edition. Maryland Heights, Mo: Mosby Elsevier Publishers; 2009.

34. Faul F, Albrechts C, Erdfelder E, Buchner A, Albert-Georg L: Statistical power analyses using $\mathrm{G}^{*}$ power 3.1: tests for correlation and regression analyses. Behav Res Methods 2009, 41(4):1149-1160.

35. Faul F, Albrechts $C$, Erdfelder E, Lang AG, Buchner A: G*power 3: a flexible statistical power analysis program for the social, behavioral, and biomedical sciences. Behav Res Methods 2007, 39(2):175-191.

36. Joshi AV, Nau DP, Kalsekar IK: An appraisal of health-related quality of life instruments for use in patients infected with human immunodeficiency virus disease. Value Health 2001, 4(2):136.

37. Lima MG, Barros MBA, César CLG, Goldbaum M, Carandina L, Ciconelli RM: Health related quality of life among the elderly: a population-based study using SF-36 survey. Cad Saúde Pública, Rio de Janeiro 2009, 25(10):2159-2167.
38. Shapiro D, Tambashe O: Employment, education, and fertility behavior in Kinshasa: some preliminary evidence. Populat Res Policy Rev 1997, 16(3):259-287.

39. Ware JE Jr, Kosinski M, Dewey JE: Version 2 of the SF-36 Health Survey. Quality Metric Incorporated: Lincoln, Rl; 2003.

40. Ware JE, Gandek B: The SF-36 health survey: development and use in mental health research and the IQOLA project. Int J Ment Heal 1994, 23:49-73.

41. Ware JE: Measuring patients' views: the optimum outcome measure. British Med J 1993, 306:1429-1430.

42. Ware JJ: SF-36 health survey manual and interpretation guide. Boston, MA: The Health Institute, New England Medical Center; 1993.

43. Jenkinson A, Layte L, Wright R, Coulter A: The UK SF-36: An analysis and interpretation manual: A guide to health status measurement with particular reference to the short form 36 health survey. Oxford: Health Services Research Unit; 1996.

44. Lyons RA, Wareham K, Lucas M, Price D, William J, Hutchings HA: SF36 scores vary by method of administration: implications for study design. J Public Health 1999, 21:41-45.

45. Möller PH, Smith R, Petr P: The SF-36 questionnaire: a tool to assess healthrelated quality of life: 2000. Retrieved 12 May 2008. http:// www.zsf.jcu.cz/ structure/departments/kvz/. . ./12DotaznikSF36.doc/.

46. Ware JE Jr, Hays RD: Methods for measuring patient satisfaction with specific medical encounters. Medical Care 1998, 26:393-402.

47. Wilson D, Parsons J, Tucke G: The SF-36 summary scales: problems and solutions. Soz Praventivmed 2000, 45:239-246.

48. Folkman S, Lazarus R: S: Manual for the ways of coping questionnaire. Palo Alto: Consulting Psychologists Press; 1988.

49. Folkman S, Moskowitz JT: Coping: Pitfalls and promise. Annu Rev Psychol 2004, 55(1):745-774.

50. Lazarus RS, Folkman S: Stress, appraisal and coping. New York: Springer; 1984.

51. D'Souza MS, Somayaji G, Nairy KS: Determinants of reproductive health and related quality of life among Indian women in mining communities. J Adv Nurs 2011, 67(9):1963-1975.

52. Indian Council of Medical Research: Ethical guidelines for biomedical research on human participants. New Delhi: ICMR; 2000. Retrieved April 7, 2005, from http://www.icmr.nic.in/bioethics.html.

53. Babbie E: The basics of social research. Belmont, CA: Wadsworth; 2002.

54. Homan R: The ethics of social research. London: Longman; 1991.

55. Stark R, Robert L: Contemporary social research methods. Belmont, CA: Wadsworth \& Thomson; 2002

56. Kalantar-Zadeh K, Kopple JD, Block G, Humphreys MH: Association among SF36 quality of life measures and nutrition, hospitalization, and mortality in hemodialysis. J Am Soc Nephrol 2001, 12(12):2797-2806. Retrieved from January 2, 2007. http://www.nephrology.rei.edu/qol.htm.

57. MANOVA and ANOVA: Retrieved December 62007 http://faculty.chass.ncsu. edu/garson/PA765/manova.htm.

58. Stevens J: Applied multivariate statistics for the social sciences. 4th edition. Mahwah, NJ: Lawrence Erlbaum Associates; 2002

59. Tabachnick BG, Fidell LS: Using multivariate statistics. 5th edition. Boston: Allyn and Bacon; 2006.

60. Karlsson I, Berglin E, Larsson PA: Sense of coherence: quality of life before and after coronary artery bypass surgery: a longitudinal study. J Adv Nurs 2000, 31(6):1383-1392.

61. Panagopoulou E, Montgomery A, Benos A: Quality of life after coronary artery bypass grafting: evaluating the influence of preoperative physical and psychosocial functioning. J Psychosom Res 2006, 60:639-644.

62. Rumsfeld JS, MaWhinney S, McCarthy M Jr, Shroyer ALW, VillaNuev CB, O'Brien M: Health related quality of life as a predictor of mortality following coronary artery bypass graft surgery. JAMA 1999, 281(140):1298-1303.

63. Tung $H H$, Anita $H$, Jen W: Coping, anxiety and quality of life after coronary artery bypass graft surgery. J Adv Nurs 2008, 61(6):651-663.

64. Hwang SL, Liao WC, Hwag SF, Chang Y, Hwang TY: Coping with the stress before and after heart surgery: a follow-up study. Thui-Zi Med J 1997, 9(1):53-61.

65. Gielen AC, O'Campo PJ, Faden RR, Kass NE, Xue X: Interpersonal conflict and physical violence during the childbearing year. Soc Sci Med 1994, 39(6):781-787

66. Krishnan S, Corinne H, Rocca A, Hubbard E, Subbiah K, Edmeades J, Padian NS: Do changes in spousal employment status lead to domestic violence? Insights from a prospective study in Bangalore, India. Soc Sci Med 2010, 70:136-143. 
67. Williams DR, Collins C: US socioeconomic and racial differences in health: patterns and explanations. Annu Rev Socio/ 1995, 21:349-386.

68. Williams DR: Race and health: Basic questions, emerging directions. Ann Epidemiol 1997, 7:322-333.

69. Wilson IB, Cleary PD: Linking clinical variables with health related quality of life: a conceptual model of patient outcomes. JAMA 1995, 273(1):59-65.

70. Yu ES, Liu W: US national health data on Asian Americans and pacific islanders: a research agenda for the 1990s. Am J Public Health 1992, 82:1645-1652

71. Panda P, Agarwal B: Marital violence, human development and women's property status in India. World Dev 2005, 33(5):823-850.

72. Patel V, Kirkwood B, Pednekar A: Gender disadvantage and reproductive health risk factors for common mental disorders in women. Arch Gen Psychiatry 2006, 63:404-413.

73. Firestone JM, Harris RJ, Vega WA: The impact of gender role ideology, male expectancies, and acculturation on wife abuse. Int J Law Psych 2003, 26:549-564.

74. Mohamadian H, Eftekhar H, Rahimi A, Mohamad HT, Shojaiezade D, Montazeri A: Predicting health related quality of life by using a health promotion model among Iranian adolescent girls: A structural equation modeling approach. Nurs Heal Sci 2011, 13:141-148.

75. Karlsen B, Oftedala B, Bru E: The relationship between clinical indicators coping styles, perceived support and diabetes related distress among adults with type 2 diabetes. J Adv Nurs 2011, 68(2):391-401.

76. Welbourne JL, Eggerth D, Hartley TA, Andrew ME, Sanchez F: Coping strategies in the workplace: relationships with attributional style and job satisfaction. J Vocat Behav 2007, 70:312-325.

doi:10.1186/1477-7525-11-9

Cite this article as: D'Souza et al:: Factors associated with health-related quality of life among Indian women in mining and agriculture. Health and Quality of Life Outcomes 2013 11:9.

\section{Submit your next manuscript to BioMed Central and take full advantage of:}

- Convenient online submission

- Thorough peer review

- No space constraints or color figure charges

- Immediate publication on acceptance

- Inclusion in PubMed, CAS, Scopus and Google Scholar

- Research which is freely available for redistribution 